\title{
Chapter 6. Obligation to Judge or Judging Obligations: The Integration of Philosophy and Science in Francophone Philosophy of Science
}

\author{
Massimiliano Simons
}

'Moreover, the major lesson that the philosopher must learn from the evolution of science is that philosophy itself must be amended. ${ }^{1}$

\section{Introduction: What French Epistemology can Offer iHPS}

At the beginning of the 1970s, the Hungarian-born philosopher of science Imre Lakatos famously claimed: 'Philosophy of science without history of science is empty; history of science without philosophy of science is blind. ${ }^{2}$ In the wake of this slogan, integrated History and Philosophy of Science (iHPS) has often been understood in two ways. Firstly, Philosophy of Science (PS) needs History of Science (HS) for its content. A good illustration of this is the plea made in the 1980s by authors such as Ian Hacking or Peter Galison for the necessity of a 'philosophy of experiment'. These authors argued through specific historical case studies that PS must be enriched by a second dimension: science is more than just theory, it also includes a specific logic of experimentation, which 'has a life of its own'. 3

Secondly, PS can also be deemed necessary for HS because certain discussions about science cannot be resolved through purely empirical means. Take the debate between realism and constructivism, a practical example of which is whether DNA has an independent existence or is rather a product of scientific research. Philosophers such as Alan Nelson have argued that such questions cannot be resolved by historical means only, but also need philosophical work. ${ }^{4}$

Both these examples show that iHPS is warranted. Nevertheless, thinkers such as Larry Laudan have concluded that 'historically based philosophy of science often remains more a slogan than a reality'. ${ }^{5}$ More recently Jutta Schickore has argued that the major reason for this unsuccessful 
integration is the 'confrontational model' that 'has dominated the debates about iHPS until today'. Schickore here is referring to how in iHPS, historical case studies are merely seen as testing grounds for abstract philosophical theories, and she argues that such a model is 'highly problematic, best to be abandoned. ${ }^{6}$ Instead she argues for a hermeneutical approach, starting from the idea that PS always already implies a historical perspective. iHPS should be about this interconnectedness of PS and HS.

The aim of this chapter is to show how Francophone PS, or what is called French (historical) epistemology, embodies this interconnectedness. Moreover, a novel approach to what constitutes French epistemology will be developed here, going beyond a purely historical survey or a reevaluation of a range of concepts found in this tradition. ${ }^{7}$ The aim is instead to highlight two methodological principles at work in French epistemology that are often in tension with one another, but are not recognized as such in the literature. This will be done in the first section of the chapter by highlighting some general characteristics of French epistemology and subsequently elaborating these two principles. First of all, there is a primacy of science over philosophy: for French epistemologists scientific practices, and not philosophy, should provide the relevant categories by which these practices can be understood. Secondly, at the same time, French thinkers feel the obligation to make a normative judgement about the history of science. ${ }^{8}$ The foundation for such normative judgements remains disputed, especially in the light of the first principle.

In the second section of this chapter, this tension will be illustrated by one of French epistemology's central figures, namely Gaston Bachelard. Both principles are present in his work: the primacy of science over philosophy in his 'surrationalism', with his normative judgements about the history of science being present in his distinction between lapsed and sanctioned history. The third and final part of this chapter will further argue that these principles are still at work in contemporary Francophone philosophers such as Michel Serres, Bruno Latour and Isabelle Stengers, a fact neglected within the literature. Their work must be understood as still being loyal to the principle of the primacy of science, but as dealing with the normative question in a rather different way. This novel approach, that I will call 'judging obligations', will be illustrated through the work of Stengers.

As stated before, the goal is not solely to give a historical overview, but to show how these ideas are useful for contemporary discussions. First of all, the principle of the primacy of science can be 
a very productive tool to develop a hermeneutical approach to iHPS. Secondly, the question of normativity will be readdressed. Authors within iHPS have often noted that there is a tension between a descriptive HS and a normative PS. ${ }^{9}$ For this dilemma, Stengers offers a novel way out, in which one can both aim for comprehensive historical descriptions and nevertheless allow normative judgements about scientific practices.

\section{Section 1. French Historical Epistemology: An Overview}

\subsection{The Primacy of Science Over Philosophy}

French epistemology can be seen as a distinct way of integrating PS and HS, different from those in the Anglo-American or analytic tradition. Traditionally, one associates PS with attempts to formulate specific criteria for scientificity. Often the aim is to conceptualize a timeless model of science, namely a model that would work for any specific moment in time. Moreover, analytic PS tries to create a norm for scientific practice, i.e. to specify a way in which science should behave rather than dealing with how it actually behaves. In this sense PS has the task of dictating to the scientist how to do science. It is precisely such an a priori approach that many scholars in iHPS find problematic and to which they aim to offer an alternative.

In France, however, the philosophical landscape is completely different. There has never been a real distinction between PS and HS that has needed to be bridged in the first place. Rather, in French epistemology, PS and HS have always been integrated in a very particular way. There are several explanations for this. Firstly, there are institutional reasons. For instance, the first French chairs and institutions devoted to HS were founded by philosophers such as Gaston Milhaud (18581918) and Abel Rey (1873-1940). Moreover, French philosophy students have always had to combine their philosophical studies with a scientific discipline. ${ }^{10}$

Secondly, there is the intellectual legacy of Auguste Comte (1798-1857), who claimed that the only significant way to do epistemology is through HS. The latter is thus chosen as a method for non-historical goals: if French epistemologists write histories of science, it is never to focus on finding out specific historical details, but in order to 'write the history of the mind' ${ }^{11}$ The French 
epistemologist Léon Brunschvicg (1869-1944) illustrates this by refusing to label himself as a historian, despite having written several historical studies about physics and mathematics, and instead claiming that his task was 'not to know the nature of things, but to tell how the human mind works'. ${ }^{12}$

Brunschvicg contrasted his own 'philosophy of thought' with traditional PS. According to him, the latter was the attempt to flesh out a general framework for the conditions of the possibility of thought with the result of merely imposing on scientific thinking some historically situated categories. His own philosophy of thought, on the other hand, followed 'the course of thought with all the twists and sharp turns, the steady lakes and rapid waterfalls, the natural rivers'. ${ }^{13}$ Brunschvicg's contemporary, Émile Meyerson (1859-1933), made a similar distinction between 'philosophy of nature' and 'philosophy of the intellect'. For Meyerson specific historical facts are not relevant as such, since he 'only deals with them as indicators of the role they played in reasoning'. ${ }^{14}$

At first sight it might seem strange that history could be of any help in understanding the human mind since the latter is traditionally the object of psychology. French epistemologists were, however, deeply critical of psychology's methods. They were especially skeptical towards introspective epistemology, where the mind looks inward and tries to understand itself by selfreflection. According to French epistemologists there is no reason to believe that the mind has immediate access to its own content.

In his Course positiviste, for instance, Comte refuted the 'psychological method' by which the mind 'pretends to accomplish the discovery of the laws of the human mind by contemplating it in itself ${ }^{15}$ For him, this kind of enquiry only leads to biases and prejudices. The only 'scientific' way to understand how knowledge is produced is by looking at its history, namely HS. Similarly, Meyerson claimed that reason 'does not know itself, because of the simple fact that it cannot observe itself. All one could know of its proper functioning, can only be concluded through the analysis of its products. ${ }^{16}$

From this perspective a different idea of philosophy was developed. Philosophy should not impose its categories on scientific practices but must respect their historical fluidity. One of the clearest examples of this is Jean-Toussaint Desanti's (1914-2002) La philosophie silencieuse (1975) in which the author criticized several forms of PS. Predating Schickore's diagnosis by almost forty 
years, Desanti dismissed a PS that would reduce scientific theories to mere illustrations of philosophical questions. According to Desanti, such a PS translates scientific practices into philosophical questions that, allegedly, only philosophers would be able to ask and answer. Desanti sketches a whole history of such philosophical reductions of science, or what he calls an 'interiorization' of science by philosophy, be it an interiorization in the Eidos (Plato), the human understanding (Descartes, Spinoza), the subject (Kant), the concept (Hegel) or consciousness (Husserl). They all ignore what Desanti called une philosophie silencieuse (a silent philosophy), the autonomous philosophical productivity of scientific practices themselves: 'Within the philosophical field organized in such a way, the sciences end up (in the eyes of the philosophers, to be clear) having no existence but the one attributed to them by the questions posed by the philosophers'. ${ }^{17}$ According to the traditional view, scientists know nothing about their own practices and need PS to articulate their truth. For Desanti, however, such a perspective ignores that scientists themselves have the capability of producing philosophically interesting categories and distinctions.

One of the central principles of French epistemology is thus, what I will call the primacy of science over philosophy: the idea that philosophy should not impose its categories on the history of science but should follow its open and productive movement. In this sense, French epistemologists mobilize HS to problematize the idea of a fixed set of philosophical categories to grasp the nature of science.

\subsection{The Question of Normativity}

This idea of the primacy of science over philosophy, however, often comes into conflict with another constant in French epistemology, namely the question of normativity. Comte and Meyerson both recognized, for example, the shifting history of the mind, while stressing that, although the products of science are diverse, there is nonetheless an all-encompassing principle at work. For Comte this principle was the law of the three stages, for Meyerson the principle of identity: in both cases, the plurality of the world must be united in one law. ${ }^{18}$ Thus, although they criticized traditional PS for imposing its own norms on the history of science, at the same time both introduced a normative criterion by which they judged history. 
Other French epistemologists remained more loyal to the primacy of science, by stressing the openness of the history of science. Brunschvicg, for instance, dismissed introspective epistemology not merely because of epistemological doubts, but also for ontological reasons. Reason is, according to him, ontologically defined as a dynamic process, and therefore always shifting throughout its history. It is for this reason that Brunschvicg, although deeply inspired by Kant, strongly criticized his predecessor's fixed framework of categories. For Brunschvicg, 'we are more faithful than Kant to the spirit of critical idealism if we reject the table of univocal categories in order to follow the dynamism and plasticity of intellectual functions' ${ }^{19}$

To understand such an ontological claim, another important characteristic of French epistemology has to be taken into account besides the institutional setting and Comte's legacy mentioned in the introduction: namely, the intellectual context that existed at the beginning of the twentieth century. French epistemologists working at that time were confronted with foundational crises in mathematics and physics. ${ }^{20}$ It is not necessary to discuss the origins or development of these crises here, since what is important is solely how philosophers understood them to be undermining the traditional foundations for rationality. How can we still be sure that our beliefs are rational if there can be historical breaks in our understanding, such as the discovery of non-Euclidean geometry or the theory of relativity?

One could interpret projects like Logicism or Husserlian phenomenology as attempts to recreate a new firm foundation for rationality. Some French epistemologists, however, took a different approach. Rather than trying to find a firm foundation for all scientific revolutions, authors such as Brunschvicg claimed that rationality resided within the revolutionary act itself. Historicity is not seen as a problem for rationality, but precisely as its ground: science is rational not despite, but because of its historical shifts. The same tension led André Lalande (1867-1963), another French epistemologist, to the distinction between 'a constituted reason and a constitutive reason' ${ }^{21}$ Behind the superficial discontinuities of constituted fields of reason lies a constant normative constitutive reason. Moreover, the discontinuities are precisely the proof of the continuous rational action of this constitutive reason.

Brunschvicg and Lalande thus mobilized the primacy of science in a novel way, namely by invoking it against the normative principles of other French epistemologists, such as Comte or Meyerson. The history of science is not guided by an atemporal goal, but rather, is subjected to an 
'indefinite progress'. ${ }^{22}$ This tension between the primacy of science and normativity is at the core of many debates within French epistemology. This is especially clear in the work of Brunschvicg's student, Gaston Bachelard (1884-1962). In the next section Bachelard's 'surrationalism' will be explored in more detail. Firstly, because Bachelard is one of the most influential authors within French epistemology; secondly, because it is his work that authors like Serres and Latour later criticized.

\section{Section 2. The Philosophy of Gaston Bachelard}

\subsection{Bachelard's Surrationalism}

In Bachelard's oeuvre, the principle of the primacy of science over philosophy is present under the banner of his 'open rationalism', or what he terms surrationalism. ${ }^{23}$ For Bachelard, rationalism cannot boil down to a series of all-encompassing fixed categories which determine how we think and act. He contrasted this 'closed rationalism' with his own 'open rationalism', which stressed that the act of rationality consisted in overcoming predetermined categories of thought by creating new ones. Bachelard wanted 'to place reason inside the crisis, to prove that the function of reason is to provoke crises' ${ }^{24}$ Similarly to the subversive nature of surrealism, surrationalism aimed to break with the conservatism of closed rationalism and become an avant-garde rationalism by grasping the novel ways in which rational thinking occurs within contemporary sciences. For Bachelard 'science instructs reason. Reason has to obey to science, a more evolved science, an evolving science.'25

This openness Bachelard was looking for is, however, not located in traditional philosophy but instead within the sciences themselves. At the centre of his work is therefore a tension between philosophy and science. For him, the sciences continually revise their theories, while philosophy tends to be conservative about them, seeing them as atemporal and universal. Like Desanti, Bachelard claimed that philosophers often try 'to apply a necessarily finalist and closed philosophy to open scientific thought'. ${ }^{26}$ Such PS does not recognize that 'science ordains philosophy by itself $^{27}$ and that 'contemporary science is philosophical at its core'. ${ }^{28}$ The primacy of science implied articulating the internal philosophical categories at work within scientific practices, rather than imposing those made up by philosophers. 
This idea was also at work in his famous notion of the epistemological rupture 'between ordinary knowledge and scientific knowledge' ${ }^{29}$ This rupture implies a break with ordinary imagination, but also with spontaneous philosophical theories about science. 'The scientific mind precisely consists in the bracketing of the philosophy one starts with. Just as experimental activity, philosophy linked to scientific activity must be nuanced and, as a consequence, be mobile. ${ }^{30}$ But traditional PS does not do this, so according to Bachelard's famous words, 'science does not have the philosophy it deserves'. ${ }^{31}$ And this is precisely what Bachelard aimed to create in his own work, an open rationalism that respects the primacy of science over philosophy:

It would therefore be interesting, we believe, to understand scientific philosophy on its own, to judge it without preconceived ideas, outside, moreover, the too strict obligations of traditional philosophical vocabulary. In fact, science creates philosophy. Philosophers must therefore adjust their own language in order to translate the contemporary [scientific] thinking in all its flexibility and mobility. ${ }^{32}$

To really grasp what is going on in the scientific practices, Bachelard argued it is necessary to look at the history and development of these sciences. Thus, Bachelard exemplifies the extent to which, for French epistemology, an iHPS is the only way to understand scientific practices. Against problematic abstract philosophical reflection, Bachelard proposed 'that it is at the level of particular examples that the philosophy of science can give us general lessons'. ${ }^{33}$

\subsection{Bachelard and the Obligation to Judge}

Using the example of Bachelard, I have shown what the principle of the primacy of science entails. This element of Bachelard's work has not received the attention it deserves within secondary literature and has therefore been stressed here. What has, however, often been discussed is how the second principle is present in his work, namely the question of normativity.

As many scholars have noted, a central element of Bachelard's philosophy is his claim that it is always necessary to make normative judgements within HS, while taking present-day science as the normative criterion. ${ }^{34}$ This stance is often called 'presentism', though Bachelard's version of it is of a specific kind. ${ }^{35} \mathrm{He}$ opposed the work of both the epistemologist and the historian. The historian searches for and accumulates facts without making normative judgements. This model, however, does not work for HS, because 'it does not take into account that every historian of 
science is necessary a historiographer of Truth'. ${ }^{36}$ The element of truth brings in a specific normative element that other domains of history lack. This is a strong claim and not widely shared in contemporary HS. A further analysis of why French epistemologists such as Bachelard nevertheless made such a claim is therefore necessary, and can best be elaborated through one of Bachelard's pupils, Georges Canguilhem (1904-1995). ${ }^{37}$

In his lecture 'The object of the history of science', Canguilhem articulated the normativity at stake by contrasting the object of science and the object of HS. The object of science can be considered as a 'natural object', for instance, crystallography studies crystals, and biology studies organisms. The object of HS, however, is a series of statements about these natural objects, statements made within a particular culture. In this sense, the objects of science and of HS are different, and are respectively that of a natural object, and that of a cultural object. According to Canguilhem this leads to at least five further differences between their objects. First of all, the 'object of historical discourse is, in effect, the historicity of scientific discourse, inasmuch as this historicity represents the carrying out of an internal law-governed project, but one which is traversed by accidents, retarded or deflected by obstacles, interrupted by crises, i.e. moments of judgements and of truth'. Secondly, the object of HS is something that evolves, and concerns 'an object to which incompleteness is essential'. ${ }^{38}$ HS cannot be the natural history of a given object with a fixed identity, but raises the question of the identity of the object within history.

Thirdly, it follows that 'the object of the historian of science can only be delimited by a decision which assigns it its interest and importance'. ${ }^{39}$ The historian is therefore in need of a norm to determine what to include and exclude as part of the science he or she wants to examine. Fourthly, as a result of this delimitation, it also has a necessary connection to realms which are typically considered non-scientific: ideology and society that themselves have to be defined by the enquiry. The object of HS is therefore not self-contained, but must be constructed. Finally, to transgress a mere 'chronological register', HS must be seen as an 'axiological activity, the search for truth' ${ }^{40}$ To become more than a mere list of scientific instruments, texts and statements, in order to grasp the normative force of scientific arguments, HS has to become normative itself. One has to grasp the specific field of concepts, theories and ideas of a certain period, which implies a certain normative choice. For Canguilhem, such a choice has to be made in light of present-day findings within the scientific discipline of which the examined part of history is seen as its history. 
For similar reasons Bachelard considered the history of physics and chemistry as implying a normative perspective, which judged historical episodes in the light of the present. This did not mean that such episodes were seen as necessary steps with the present as their goal, but rather that the present always rewrote its own history from this necessity of normativity. For Bachelard this resulted in a distinction between 'lapsed history' (histoire périmée) and 'sanctioned history' (histoire sanctionnée). ${ }^{41} \mathrm{He}$ saw the former as the parts of science that, from a contemporary perspective, were excluded as non-science, while the latter referred to the preserved elements.

Such a harsh distinction must moreover be situated within Bachelard's broader philosophy. First of all, Bachelard endorsed the goal of French epistemology to write a history of the mind. The aim was therefore to grasp the normative force of reason through its history, not the historical details.

Secondly, for Bachelard there was a clear pedagogical task present in his philosophy. ${ }^{42}$ Describing the struggle of past science with certain epistemological obstacles, such as ordinary experience or naïve philosophical theories, allowed present students of science to be wary of possible missteps and confusions. HS, for Bachelard, was thus about the formation of the scientific mind. So-called Whiggish history of science fails in this objective, since it tends to either present contemporary theories as self-evident - and thus forgets the danger of certain epistemological obstacles that prevent many from fully understanding these theories - or reproduces certain naïve images - such as seeing atoms as solar systems - and thus slowing down the dynamics of the scientific mind, rather than freeing it from these images.

\section{Section 3. From Epistemological to Political Normativity}

\subsection{A New Generation of Francophone Philosophers of Science}

In the previous sections, I showed how French epistemologists conceived the relationship between PS and HS. I showed what the principle of the primacy of science consisted in: a principle that can be useful for developing an approach to iHPS that avoids the confrontational model, but promotes what Schickore calls a 'hermeneutical' approach. Their views on normativity, however, might not be shared by contemporary iHPS, but nevertheless offer a strong case of why a certain normativity within iHPS can still be warranted. 
More recent developments in Francophone PS have often been neglected in overviews of French epistemology, but in fact offer an even more promising normative project. Michel Serres, Bruno Latour and Isabelle Stengers, though in several ways opposed to French epistemology, share some of its fundamental principles, while drawing radically different normative conclusions from them. To relate them to French epistemology is not self-evident, since their projects have several fundamental differences, and they are often explicitly in opposition to French epistemology. ${ }^{43}$ Serres, for instance, states:

Yes, I wrote my thesis under Bachelard, but 1 thought privately that the "new scientific spirit" coming into fashion at that time lagged way behind the sciences. [...] The model it offered of the sciences could not, for me, pass as contemporary. This new spirit seemed to me quite old. And so, this milieu was not mine. ${ }^{44}$

But, in this passage Serres is criticizing Bachelard for specific reasons. Serres is not claiming that there have been no relevant shifts within the history of science, nor that such shifts would be unworthy of philosophical attention. Rather, he claims that Bachelard is lagging behind the newest developments, since in mathematics for instance, 'instead of speaking of algebra, topology, and set theory, [Bachelard] referred to non-Euclidean geometries, not all that new' ${ }^{45}$ Serres accused Bachelard of not being loyal enough to the principle of the primacy of science by missing out on the most recent scientific developments. According to Serres, therefore, Bachelardian epistemology was still not open enough. ${ }^{46}$

For Serres, these new scientific developments also resulted in a greater reflexivity within the sciences about their own philosophical categories. The consequence of such an increased reflexivity was a new tension within the self-identity of the epistemologist. If the sciences became capable of articulating their own philosophical categories, then the traditional French epistemological project was reduced to a mere repetition of what scientists did themselves. In what sense, then, did the 'philosopher's work differ from that of a journalistic chronicler, who announces and comments on the news? ${ }^{47}$ Either the epistemologists merely repeated the sciences, or their projects aimed to do something more, but this extra element would involve a form of philosophical speculation, going beyond what the sciences said. Such speculation thus implied a tension within the principle of the primacy of science. 
Moreover, Serres claimed that Bachelard had always done more than mere description. There had always been a speculative-normative project at work, namely the above described presentism, looking for epistemological obstacles and epistemological ruptures. For someone like Serres, the project of French epistemology was a crypto-normative project, starting from a philosophical model of purification: true science purified itself from all the obstacles, from imagination, from myth. Against this Serres stated that 'there is no purer myth than the idea of a science purified from all myth, ${ }^{48}$

This criticism was even clearer in the work of Serres' pupil, Bruno Latour. In Laboratory Life, Latour criticized Bachelard's epistemological project, especially the claim that science was rational in so far it succeeded to break with ordinary experience and imagination. ${ }^{49}$ Latour observed no such break in his fieldwork in scientific laboratories. For him, notions such as irrationality were never genuine descriptions of science, but rather accusations that aimed to discredit an opponent. ${ }^{50} \mathrm{~A}$ genuine understanding of science should not start from such unquestioned distinctions as rational versus irrational.

Latour's criticism was partly inspired by the Strong Programme of the Sociology of Scientific Knowledge (SSK). ${ }^{51}$ But it is equally important to note that Latour went further than these sociologists. This led to a different appreciation of what to do with such distinctions as rational/irrational or true/false. Rather than ignoring or bracketing them, as SSK does, 'our contention is not just that sociological explanation should be impartial with respect to truth and falsity, and that both sides of the dichotomy require explanation. Our argument is that the implicit (or explicit) adaption of a truth value alters the form of explanatory account which is produced. ${ }^{52}$ For Latour, although such distinctions could not be used as explanations, they were nevertheless real by virtue of their effects in the scientific field. Since such distinctions were found within scientific practices, often at moments of controversy, they should be taken into account as well. Latour thus invoked the principle of the primacy of science by arguing that, since these distinctions were used within scientific practices, we should therefore track how scientists used them and not just dismiss them as ideology.

Moreover, Latour's work can be seen as a further development of this principle, by stressing the necessity to follow all forms of associations and connections one finds in the scientific practices. Latour, for instance, stated that 
Instead of defining a priori the distance between the nucleus of scientific content and its context, an assumption that would render incomprehensible the numerous short-circuits between ministers and neutrons, science studies follows leads, nodes, and pathways no matter how crooked and unpredictable they may look to traditional philosophers of science. ${ }^{53}$

The scientific actors should decide which distinctions are relevant and which are not, even if it leads us 'outside' of science, and philosophers 'should be as undecided as the various actors we follow as to what technoscience is made of; to do so, every time an inside/outside division is built, we should follow the two sides simultaneously, making up a list, no matter how long and heterogeneous, of all those who do the work'. ${ }^{54}$ This is Latour's famous dictum to 'follow the actors', which can be interpreted in the light of the primacy of science over philosophy. A similar rule can be found in the work of Isabelle Stengers, who wants to give a description of the scientific practices that 'does not insult the scientists'. 55

\subsection{Judging the Obligations of the Scientists}

Serres, Latour and Stengers were quite close to the earlier generation as far as the principle of the primacy of science is concerned, but they did not follow Bachelard's normative project. In fact, similarly to authors such as Brunschvicg before them, they played out the principle of the primacy of science against the normative project of their predecessor. Precisely Bachelard's ideas about how scientific rationality always excludes imagination, and how such a distinction should be mirrored in HS as lapsed versus sanctioned history, prevented him from truly endorsing the primacy of science. According to this new generation, in order to follow the sciences, the whole way through, the philosopher should not be the judge over what is and is not part of science.

Does this mean that philosophers should give up any ambition to make normative judgments about scientific practices? Although it might seem so, I would argue that this is not the main message. The conclusion I wish to draw from these recent criticisms is that the problem is not the fact that Bachelard judges, but the manner in which he judges. What was at stake for this new generation was not the normativity of Bachelard's project per se, but its implicit endorsement of a certain political project: one that made a distinction between science, which knows and as such is epistemologically superior to non-science, which does not. ${ }^{56}$ This implied a problematic reaffirmation of the political power of the sciences over the rest of society. One should make an 
analytical distinction between the epistemological project of French epistemology that endorses the primacy of science and their political project of granting science hierarchical autonomy from other practices. What authors such as Serres, Latour or Stengers had in mind was a different political project: one that respected the primacy of science - follow the actors, do not insult the scientists - but at the same time conceptualized a new politics of science. ${ }^{57}$

It is this project that can provide another useful tool for contemporary iHPS, as illustrated by the work of Stengers. Similarly to Latour and Serres, she agrees that there is no essential distinction between science and non-science; she nevertheless argues that such a distinction is constructed by the actors in the field. This distinction relies, for her, on two elements, namely a range of requirements and a range of obligations. ${ }^{58}$ For Stengers the essential element to be respected are the obligations, while the requirements can be the object of a normative judgement. A different politics of science is therefore possible, namely by replacing the requirements, while respecting their obligations, and thus the primacy of science.

In short, a requirement refers to the fact that some distinctions are deemed necessary in order for a practice to work. Think for instance of the distinction between science and non-science, or science seen as autonomous from external socio-economic history. In the current scientific practices these distinctions are claimed as requirements, for, otherwise, scientists would allegedly lose themselves in discussions with their financial sources, who would impose their own goals, or with the general public, who might want to have a say in the development of science and its innovations. Many contemporary scientists argue that, in order to function, scientific practices require these distinctions to be maintained, even if they are constructed.

However, these requirements are not enough on their own. Scientific practices are also shaped by their specific obligations. This is related to the idea that scientists do not get involved in scientific controversies because they choose to. Rather they feel obligated to by the phenomena or the problem itself. What scientists find interesting and worth pursuing is not something they freely decide themselves, but rather is partly caused by the phenomena that spark their interest. Scientists thus feel a certain obligation being imposed from the outside, from the phenomena they try to take into account. Scientists are then not speaking in their own name, but in the name of these phenomena. An obligation thus refers to the fact that there is a relation that makes a difference: things with or without taking the phenomena into account are not the same. 
For Stengers, such obligations are at work in all types of practices and can be of many sorts. For instance, within religious practices an obligation can consist in Virgin Mary who obliges believers to take Her into account by, for example, asking them to go on a pilgrimage. ${ }^{59}$ Stengers stresses that her 'project does not thereby seek to ground a privilege for the sciences, which alone would escape sociological analysis. The same type of questions should be posed with regard to other practices. ${ }^{60}$ In the case of the experimental practices, scientists are obligated to speak with their phenomena in mind. In the same way a pilgrimage is experienced as being imposed from outside the believer, scientists feel obligated to make sure everything necessary is done in order for their phenomena to be properly accounted for in scientific discussions. It is this obligation towards the phenomena that is at the core of the scientific practice.

Scientists, therefore, have certain obligations and act as they do in light of them. But although these obligations are experienced by scientists, their nature remains opaque. The success of answering to these obligations, allowing a certain scientific practice to function, depends on what Stengers calls an 'event'. An event refers to the situation in which a scientific practice has found a way to properly articulate its phenomena. But again, the nature of this success remains opaque and does not grant the participants to this event a privileged explanation of why this approach is successful. The crucial point is that one can make a separation here between two elements, namely one can aim 'no longer to deny the differences scientists claim for themselves, but to avoid any way of describing them which implies that scientists have a privileged knowledge of what this difference that singularizes them signifies ${ }^{\prime}{ }^{61}$

According to Stengers, both philosophers and sociologists of science falsely assume that if such an event has occurred, it must be transparent to its participants. Not only philosophers who try to define general criteria of rationality, but also sociologists who deny that such criteria exist, make the mistake of assuming that if such criteria cannot be properly articulated by the scientists doing the research that no such event has occurred. 'According to the viewpoint I am defending, the scope of [such] demonstration is zero, for it assumes that the foundational event can give an account of itself. ${ }^{62}$ Scientists know they have obligations, but this does not mean that what these are is fully transparent to the scientists. As Stengers writes, '[j] ust as the event, in itself, does not have the power to dictate how it will be narrated or the consequences that will be authorized on its behalf, neither does it have the power to select among its narrators' ${ }^{63}$ The consequence of this is that there is no guarantee that the specific 'requirements' scientists demand to safeguard the 
success of the event are necessary. Requirements can thus be disputed without disputing that obligations exist.

This opens up the possibility to come up with other requirements, for instance a range of requirements free from a strong distinction between science and non-science or open to contributions from citizens to scientific research without immediately compromising its scientificity. What Stengers therefore proposes is a project in which specific scientific disciplines can be politically judged, without dismissing the primacy of science. 'This is why my position clearly does not amount to defending the sciences, but to defending their singularity in order to utilize it to invent the means of a critical position that complicates their history. ${ }^{64}$ According to Stengers, social constructionist HS, such as SSK, went too far by confusing requirements with obligations and dismissing them both. Scientists are correct in protesting against such historians who disrespect their obligations, but that does not entail that their proposed requirements are indisputable. Rather, these are always open for debate.

\section{Conclusion: New Tools for iHPS}

This chapter shows that within the tradition of French epistemology and its critics, a very specific integration between science and philosophy is conceptualized. A relationship wherein any form of primacy of philosophical speculation over scientific practices is fiercely disputed. Rather, the idea is that scientific practices produce their own philosophical categories and thus a primacy of science over philosophy. The task of French epistemologists has been, therefore, to start from these elements, instead of dictating what is philosophically relevant to science. At the same time, it was made clear that a constant struggle in French epistemology remains present, where this primacy of science conflicts with the normative ambitions of French epistemologists.

This conflict was mainly shown through the work of Bachelard, creating a tension between his surrationalism and his obligation to judge the history of science. This is precisely the object of the critique of contemporary authors such as Serres, Latour and Stengers. However, their criticisms are not a dismissal of French epistemology, but can be understood as a particular radicalization of this primacy of science over philosophy. Bachelard and others were not wrong in their objectives, but failed to follow them the whole way through - there were still traces of philosophical a prioris 
in their work, resulting in the endorsements of certain political projects related to the social status of science. In that sense, the first conclusion is that to speak of a radical break between these two traditions is false. Rather one must speak of a radicalization or a revision of the "primacy of science'.

This chapter, however, aimed for more than a historical overview of recent developments within Francophone philosophy of science. It precisely aimed to highlight possible productive tools for contemporary discussions of how PS and HS should be integrated. First, the principle of the primacy of science embodies the 'hermeneutical' perspective called for by contemporary authors such as Schickshore. This essential principle of French epistemology can thus offer guidance of how such a hermeneutically-inspired iHPS should be pursued.

Secondly, this chapter addressed the question of normativity, central to many discussions in iHPS. How can a descriptive HS and a normative PS be combined? Rather than giving up any normative ambitions, French epistemology indicates several avenues through which normative elements still play a role. Not only is the 'obligation to judge' the past from the present, embodied in the work of Bachelard and Canguilhem, worth discussing, but the particular project of 'judging obligations', found in the work of Stengers, offers a similarly promising avenue for a normative iHPS.

From this perspective, there is room in iHPS for normative judgements about scientific practices. Not only in the activity of conceptually separating the obligations from their requirements, but even in a critical evaluation of the history of these obligations. Either iHPS can have the task of showing how certain obligations are under threat by developments within society, such as the rise of the contemporary knowledge economy and its focus on applications and economic gain. Or, iHPS can focus on contemporary shifts within the sciences, where certain obligations are being forgotten, badly articulated, or where different requirements for them can be conceived. But a constant in Francophone philosophy of science is the claim that scientists are at least seen as potential allies in this reform and that philosophy must be open enough to learn from them.

\section{Acknowledgements}

The research for this chapter was supported by the Flandres Research Foundation (FWO). Further I would like to thank Matteo Vagelli and Eugenio Petrovich for making the chapter possible, and 
Katleen Pasgang, Charlotte Alderwick, and the editors of this volume for their many useful comments and suggestions. 


\section{Bibliography}

Bachelard, Gaston, Le nouvel esprit scientifique (Paris: Alcan, 1934)

Bachelard, Gaston, La philosophie du non (Paris: PUF, 1940)

Bachelard, Gaston, L'activité rationaliste de la physique contemporaine (Paris: PUF, 1951)

Bachelard, Gaston, Le matérialisme rationnel (Paris: PUF, 1953)

Bachelard, Gaston, L'engagement rationaliste (Paris: PUF, 1972)

Bloor, David, Knowledge and Social Imagery (London: Routledge and Kegan Paul, 1976)

Brenner, Anastasio, 'Is There a Cultural Barrier Between Historical Epistemology and Analytic Philosophy of Science?,' International Studies in the Philosophy of Science, 29.2 (2015), 201-214

Brunschvicg, Léon, L'expérience humaine et la causalité physique (Paris: Alcan, 1922)

Canguilhem, Georges, 'The object of the history of science', in Continental philosophy of science, ed. by Garry Gutting (Oxford: Blackwell, 2005), pp. 198-207

Castelli Gattinara, Enrico, Les inquiétudes de la raison (Paris: Vrin, 1998)

Chimisso, Cristina, Gaston Bachelard : Critic of science and the imagination (London: Routledge, 2001)

Chimisso, Cristina, Writing the history of the mind (Aldershot: Ashgate, 2008)

Chimisso, Cristina, 'Narrative and epistemology: Georges Canguilhem's concept of scientific ideology,' Studies in History and Philosophy of Science, 54 (2015) 64-73

Comte, Auguste, Auguste Comte and Positivism: the Essential Writings, ed. by Getrud Lenzer (New Brunswick, Transaction, 1998)

Desanti, Jean.-Toussaint, La philosophie silencieuse ou Critique des philosophies de la science (Paris: Seuil, 1975)

Giere, Ronald 'History and Philosophy of Science: Intimate Relationship or Marriage of Convenience? (Book Review),' The British Journal for the Philosophy of Science, 24.3, (1973) 282-297

Hacking, Ian, Representing and intervening (Cambridge: Cambridge University press, 1983)

Lakatos, Imre, 'History of Science and Its Rational Reconstructions', in Scientific Revolutions, ed. by Ian Hacking (New York (N.Y.), Oxford University Press, 1981), 107-127

Lalande, André, La raison et les normes (Paris: Hachette, 1963)

Latour, Bruno, Science in action (Cambridge (Mass.): Harvard university press, 1987)

Latour, Bruno Pandora's Hope: Essays on the Reality of Science Studies (Cambridge: Harvard university press, 1999) 
Latour, Bruno and Steve Woolgar, Laboratory Life: the construction of scientific facts (Princeton: Princeton University Press, 1986)

Laudan, Larry, 'Thoughts on HPS: 20 years later,' Studies in History and Philosophy of Science, 20.1 (1989) 9-13

Loison, Laurent, 'Forms of Presentism in the History of Science. Rethinking the Project of Historical Epistemology,' Studies in History and Philosophy of Science, 60 (2016) 29-37

Meyerson, Émile, Essais (Paris: Vrin, 1936)

Nelson, Alan, 'How could scientific facts be socially constructed?', Studies in History and Philosophy of Science, 25.4 (1994) 535-547

Rheinberger, Hans-Jörg, On historicizing epistemology: An essay (Stanford: Stanford university press, 2010)

Schickore, Jutta, 'More Thoughts on HPS: Another 20 Years Later,' Perspectives on Science, 19.4, (2011) 453-481

Serres, Michel, Hermès III. La traduction (Paris : Éditions de Minuit, 1974)

Serres, Michel and Bruno Latour, Conversations on science, culture and time (Ann Arbor: Michigan university press, 1995)

Simons, Massimiliano. 'The Many Encounters of Thomas Kuhn and French Epistemology,' Studies in History and Philosophy of Science, 61 (2017) 41-50

Simons, Massimiliano, 'The Parliament of Things and the Anthropocene: How to Listen to 'QuasiObjects', Techné: Research in Philosophy and Technology, 21.2-3 (2017), 150-174

Simons, Massimiliano, 'Surrationalism after Bachelard: Michel Serres and le nouveau nouvel esprit scientifique,' Parrhesia, 28 (2018, forthcoming)

Stengers, Isabelle, Power and invention: Situating science (Minneapolis: University of Minnesota press, 1997)

Stengers, Isabelle, The invention of modern science (Minneapolis: University of Minnesota press, 2000)

Stengers, Isabelle, La vierge et le neutrino (Paris : Seuil, 2006)

Stengers, Isabelle, Cosmopolitics I (Minneapolis: University of Minnesota press, 2010) 
${ }^{1}$ Gaston Bachelard, Le matérialisme rationnel (Paris : PUF, 1953), p. 133.

${ }^{2}$ Imre Lakatos, 'History of Science and Its Rational Reconstructions', in Scientific Revolutions, ed. by Ian

Hacking (New York (N.Y.), Oxford University Press, 1981), pp. 107-127 (p. 107).

${ }^{3}$ Ian Hacking, Representing and intervening, (Cambridge: Cambridge University press, 1983), p. 150.

${ }^{4}$ See Alan Nelson, 'How could scientific facts be socially constructed?', Studies in History and Philosophy of Science, 25(4) (1994), 535-547.

${ }^{5}$ Larry Laudan, 'Thoughts on HPS: 20 years later,' Studies in History and Philosophy of Science, 20.1 (1989), 913 (p. 11).

${ }^{6}$ Jutta Schickore, 'More Thoughts on HPS: Another 20 Years Later,' Perspectives on Science, 19.4, (2011), 453481 (p. 462, p. 456)

${ }^{7}$ See respectively Cristina Chimisso, Writing the history of the mind (Aldershot: Ashgate, 2008) and Hans-Jörg

Rheinberger, On historicizing epistemology: An essay (Stanford: Stanford university press, 2010).

${ }^{8}$ This is especially clear once contrasted with Thomas Kuhn. Kuhn was heavily criticized by French epistemologists for what they saw as his lack of attention for the normative element at work within the history of science. See Massimiliano Simons. 'The Many Encounters of Thomas Kuhn and French Epistemology,' Studies in History and Philosophy of Science, 61 (2017), 41-50.

${ }^{9}$ Ronald Giere, 'History and Philosophy of Science: Intimate Relationship or Marriage of Convenience? (Book Review),' The British Journal for the Philosophy of Science, 24.3, (1973), 282-297 (p. 290).

${ }^{10}$ Cristina Chimisso, Writing the history of the mind (Aldershot: Ashgate, 2008); Anastasio Brenner, 'Is There a Cultural Barrier Between Historical Epistemology and Analytic Philosophy of Science?,' International Studies in the Philosophy of Science, 29.2 (2015), 201-214.

${ }^{11}$ Cristina Chimisso, Writing the history of the mind (Aldershot: Ashgate, 2008).

${ }^{12}$ Léon Brunschvicg, L'expérience humaine et la causalité physique (Paris: Alcan, 1922), p. xiii. (own translation)

${ }^{13}$ Ibid, p. 570.

${ }^{14}$ Émile Meyerson, Essais (Paris: Vrin, 1936), p. 118. (own translation)

${ }^{15}$ Auguste Comte, Auguste Comte and Positivism : the Essential Writings, ed. by Getrud Lenzer (New Brunswick, Transaction, 1998), p. 80.

${ }^{16}$ Émile Meyerson, Essais (Paris: Vrin, 1936), p. 206.

${ }^{17}$ Jean-Toussaint Desanti, La philosophie silencieuse ou Critique des philosophies de la science (Paris: Seuil, 1975), p. 68. (own translation)

${ }^{18}$ Comte claimed that all sciences followed a historical three-stage pattern, starting from a theological stage (explanation by divine causes), subsequently going through a metaphysical stage (explanation by abstract philosophical categories), to end up in the positive stage (explanation by laws instead of causes). Meyerson disagreed and argued that the search for causality is central to the human mind, in the sense that scientists always look for an identity relation between antecedents and consequents, expressed in a formal equation. Meyerson explained shifts in the history of science as different attempts and approaches to find such an identity relation.

${ }^{19}$ Léon Brunschvicg, L'expérience humaine et la causalité physique (Paris: Alcan, 1922), p. 550.

${ }^{20}$ See Enrico Castelli Gattinara, Les inquiétudes de la raison (Paris: Vrin, 1998).

${ }^{21}$ André Lalande, La raison et les normes (Paris: Hachette, 1963), p. 17. (own translation)

${ }^{22}$ Léon Brunschvicg, L'expérience humaine et la causalité physique (Paris: Alcan, 1922), p. 595.

${ }^{23}$ See Gaston Bachelard, La philosophie du non (Paris: PUF, 1940).

${ }^{24}$ Gaston Bachelard, L'engagement rationaliste (Paris: PUF, 1972), p. 27. (own translation)

${ }^{25}$ Gaston Bachelard, La philosophie du non (Paris: PUF, 1940), p. 144. (own translation)

${ }^{26}$ Ibid, p. 2.

${ }^{27}$ Ibid, p. 22.

${ }^{28}$ Gaston Bachelard, Le matérialisme rationnel (Paris : PUF, 1953), p. 180. (own translation)

${ }^{29}$ Ibid, p. 207.

${ }^{30}$ Gaston Bachelard, L'activité rationaliste de la physique contemporaine (Paris: PUF, 1951), p. 17. (own translation)

${ }^{31}$ Gaston Bachelard, Le matérialisme rationnel (Paris : PUF, 1953), p. 20.

${ }^{32}$ Gaston Bachelard, Le nouvel esprit scientifique (Paris: Alcan, 1934), p. 3. (own translation)

${ }^{33}$ Gaston Bachelard, Le matérialisme rationnel (Paris : PUF, 1953), p. 223.

${ }^{34}$ For instance Cristina Chimisso, Gaston Bachelard : Critic of science and the imagination (London: Routledge, 2001).

${ }^{35}$ Laurent Loison, 'Forms of Presentism in the History of Science. Rethinking the Project of Historical Epistemology,' Studies in History and Philosophy of Science, 60 (2016), 29-37. 
${ }^{36}$ Gaston Bachelard, Le matérialisme rationnel (Paris : PUF, 1953), p. 86.

${ }^{37}$ For methodological differences between the two, see Cristina Chimisso, 'Narrative and epistemology: Georges Canguilhem's concept of scientific ideology,' Studies in History and Philosophy of Science, 54 (2015), 64-73.

${ }^{38}$ Georges Canguilhem, 'The object of the history of science', in Continental philosophy of science, ed. by Garry Gutting (Oxford: Blackwell, 2005), pp. 198-207 (p. 203).

${ }^{39}$ Ibid, p. 203.

${ }^{40}$ Ibid, p. 204.

${ }^{41}$ Gaston Bachelard, 'Chapitre 1' in L'activité rationaliste de la physique contemporaine (Paris: PUF, 1951).

${ }^{42}$ Cristina Chimisso, Gaston Bachelard: Critic of science and the imagination (London: Routledge, 2001).

${ }^{43}$ First of all they are critical of the notion of 'rationality'. Secondly, they start from a fundamental different ontology. See Massimiliano Simons, 'The Parliament of Things and the Anthropocene: How to Listen to 'QuasiObjects', Techné: Research in Philosophy and Technology, 21.2-3 (2017), 150-174.

${ }^{44}$ Michel Serres and Bruno Latour, Conversations on science, culture and time (Ann Arbor: Michigan university press, 1995), p. 11.

${ }^{45}$ Ibid.

${ }^{46}$ Especially the early work of Serres aims to update Bachelard's work. See Massimiliano Simons,

'Surrationalism after Bachelard: Michel Serres and le nouveau nouvel esprit scientifique,' Parrhesia, 28 (2018, forthcoming).

${ }^{47}$ Michel Serres and Bruno Latour, Conversations on science, culture and time (Ann Arbor: Michigan university press, 1995), p. 15.

${ }^{48}$ Michel Serres, Hermès III. La traduction (Paris : Éditions de Minuit, 1974), p. 259. (own translation)

${ }^{49}$ Bruno Latour and Steve Woolgar, Laboratory Life: the construction of scientific facts (Princeton: Princeton University Press, 1986), pp. 151-153.

${ }^{50}$ Bruno Latour, Science in action (Cambridge (Mass.): Harvard university press, 1987), p. 185.

${ }^{51}$ This programme, associated with the so-called Edinburgh School, aimed to apply a sociological analysis to scientific knowledge. See David Bloor, Knowledge and Social Imagery (London: Routledge and Kegan Paul, 1976).

${ }^{52}$ Bruno Latour and Steve Woolgar, Laboratory Life: the construction of scientific facts (Princeton: Princeton University Press, 1986), p. 149n1.

${ }_{53}$ Bruno Latour, Pandora's Hope: Essays on the Reality of Science Studies (Cambridge: Harvard university press, 1999), p. 99.

${ }_{54}^{54}$ Bruno Latour, Science in action (Cambridge (Mass.): Harvard university press, 1987), p. 176.

${ }^{55}$ Isabelle Stengers, La vierge et le neutrino (Paris : Seuil, 2006).

${ }^{56}$ Isabelle Stengers, The invention of modern science (Minneapolis: University of Minnesota press, 2000), p. 26.

${ }^{57}$ Massimiliano Simons, 'The Parliament of Things and the Anthropocene: How to Listen to 'Quasi-Objects',

Techné: Research in Philosophy and Technology, 21.2-3 (2017), 150-174.

${ }^{58}$ Isabelle Stengers, Cosmopolitics I (Minneapolis: University of Minnesota press, 2010), p. 52.

${ }^{59}$ Isabelle Stengers, La vierge et le neutrino (Paris : Seuil, 2006).

${ }^{60}$ Isabelle Stengers, The invention of modern science (Minneapolis: University of Minnesota press, 2000), p. 58.

${ }^{61}$ Ibid, p. 67.

${ }^{62}$ Ibid, p. 68.

${ }^{63}$ Ibid, p. 68.

${ }^{64}$ Isabelle Stengers, Power and invention: Situating science (Minneapolis: University of Minnesota press, 1997), p. 143 